\title{
Cyber Loafing at Work Place - A Literature Review
}

\author{
${ }^{1}$ Ms. Sonali Rushiya, ${ }^{2}$ Prof. Kanchan Tolani \\ ${ }^{1}$ MBA $2{ }^{\text {nd }}$ year Student, Shri Ramdeobaba College of Engineering and Management, Nagpur \\ ${ }^{2}$ Assistant Professor, Shri Ramdeobaba College of Engineering and Management, Nagpur \\ Email:rushiyas@rknec.edu,tolanik1@rknec.edu
}

\section{Received: $20^{\text {th }}$ September 2018, Accepted: $11^{\text {th }}$ October 2018, Published: $31^{\text {st }}$ October 2018}

\begin{abstract}
In the present era, a large amount of attention is dedicated to technological advancements which have created a courageous novel work place. It has revolutionized the method in which work is carried out, and how workers/ employees can improve their productivity and efficiency. But, new opportunities and avenues for people to misbehave has been opened by entrance of technology. The study focuses, the act of employees using their companies internet access for personal use during work hour is known as cyber loafing. Cyber loafing is a type of production deviance. The study represents the relationship between cyber loafing and three important variables which are perceived organisational control, fear of formal punishment and physical leadership closeness as understood by employees. The previous study on cyber loafing, needs to be expanded by considering the impact of personality and some past unexplored situational factors. The power of big five personality factors is also tested. Whereas, on the amount of cyber loafing the existence of an internet usage policy and apparent work meaningfulness is also examined. There are two types of cyber loafing, minor cyber loafing for example employees sending and receiving personal mail at office hour) and serious cyber loafing for example online gambling, exploring adult oriented websites. Perception of employees about their co-worker and manager standards also supports to cyber loafing. These are related to minor cyber loafing not serious cyber loafing. The external focus of control also leads to other counter productive work behaviours related to minor and serious cyber loafing.
\end{abstract}

\section{Keywords \\ Cyber Loafing, Big Five Personality Traits, Cyber Slacking, Internet Access.}

\section{Introduction}

From the $21^{\text {st }}$ century, there is no doubt that advanced technology will change the scenario of diverse domains of life. There is only one technology i.e. internet which has remarkable effect on individual's life. In the new era businesses do not perform in traditional methods. Internet has provided a large platform to conduct business more easily and efficiently. Also a way of attractive employee performance. It helps businesses to reduce cost, decrease product cycle time and market products and services easily. Over last few years internet has also opened the access of deviant work place behaviour where employee explore the internet instead of performing work. It has been categorized as cyber loafing and also the deviant targeting the organisation as the cyber loafer acts directly against the company's internet system. Lim defined internet misuse as any voluntary act of employees using company's internet access during work time for exploring non job related web sites and receiving or sending emails of personal use. During study in organisation it is found that employee are more likely involve in misconduct when they think that their employer have been unfair or in the allocation of outcomes. Greenberg founds that employee counter react to unfair pay cuts by involving in theft. Skarlicki and Folgers founds that unfair employers are retaliated by employees more. On the basis of contention many contemporary workers specifically information workers are needed to be engaged in creative and flexible thinking in order to do work innovatively. It is believed that cyber slacking is not only the area of lower status employees, it can be spread among high status workers too. Some companies wills to recognise and tolerate a certain level of personal internet use whereas other company has developed organisational policies consisting various degree of disciplinary action. According to a survey $47 \%$ of employers reviewed e mail and $63 \%$ monitor internet use. At least one employee dismissed out of $50 \%$ of respondents for email and internet use. $38 \%$ company uses of software which prevents employees to operate inappropriate internet sites. When facing cyber loafing employers uses coercive strategies to obtain higher perception of organisational control by using disciplinary sanctions which elicits fear of formal punishments. It leads to employees to excess use higher internet use normative compliance. Cyber loafing is a type of production deviance .Organisational justice and neutralization examined the neglected dark sides of internet. The role of neutralization technique is to facilitate misbehaviour at work place. When employee thinks that their organisation is distributive, procedurally and interactional unjust they are likely to they are likely to raise the symbol of record as a neutralization technique to legitimise their subsequent assignation in the act of cyber loafing. The conclusion is noteworthy as a employee may not be neutralising cyber loafing but there are other more potential harmful deviant act the work place. To 
keep cyber loafing and other deviants behaviour at a minimum level within the organisation managers are needed to be aware of this fact and they must take necessary steps to neutralise these neutralisation techniques.

\section{Materials and Methods}

Studies are qualitative and exploratory in nature which gives suggestions from past research from cyber loafing. Taking into consideration the impact of personality and past unexplored situational factors. It is a study where attempt is made to identify the big five personality factors and the use of internet access at workplace for personal use. It examines big five personality factors with the presence of internet uses policy and apparent work meaningfulness on the amount of cyber loafing. Cyber slacking and personality traits are also being focused in this study. This paper is an attempt to assemble perfect pool of study done in the area deviant workplace behaviour. Due to past cyber loafing and organised them to provide more meaningful insights for future research.

\section{Result and Discussion}

Individual do not have integrations in social life as described by Anomia. Work anomia explains the relationship between employees perception organisational justice and workplace internet use. There re three types of perception- Distributive, Procedural and interactional among employees within, low as compared to high anomia. The purpose of study is to describe cyber slacker in most accurate form. Non work related use of internet among lower paid, lower prestige job is more. Cyber slacking is also frequently taking place among higher workplace status. Highly paid managers who are better educated spends more time online of personal purpose hour.

\section{Conclusion}

Workplace internet usage is growing evidently around the world. This rapid addition has led too much attention being focused on the strength of internet convention on yield; much of the work in this area has largely examined the positive productivity influences brought about through the Internet. The study is, noteworthy as it represents one of the few observed performances to delve into the area of how the Internet not only creates a brave new workplace by revolutionizing the ways in which work can be done but also transforms the ways in which loafing can be done.

The modern system of control of cyber loafing should follow a condition list view, which refuse to consider lazy, highly faithful or negligent cyber loafers, but employees conditioned by an unfair/anomic environment. There should be our personal support for directorial learning as capable of integrating 'knowledge' and achieving those behavioral improvements within the complete organization. In result, knowledge is something more than mere data or information flow charged with data. It is a structure of the individual's experiences, values (attitudes), information and know-how that permits both the gathering of new knowledge and effective action.

The Employee may cyber loaf as they may think that, they are unjustly treated therefore perceive for cyber loafing to impact their work differently because they are bored or stressed. When employees cyber loaf they show a form of retaliation against seeming organizational inequality. They like to engage in counterproductive cyber loafing. It results in a purposeful waste of productive time. They may use it as an office plaything to escape from schedule work, especially those who are stressed with their work. Sometimes cyber loafing may be advantageous for the employees as it proves to be a short break for employees as working continuously may create stress and fatigue. It helps them zone out and re focus attention on work.

\section{References}

[1] V. K. G. LIM, "The IT way of loafing on the job: cyber loafing, neutralizing and organizational justice," Journal of Organizational Behavior, vol. 23, p. 675-694, 2002.

[2] P. Z. M. D. LARA, "Relationship between Organizational Justice and Cyber loafing in the Workplace: Has "Anomia” Say in the Matter?," Cyber Psychology \& Behavior, vol. 10, no. 03, pp. 464-470. , 2007.

[3] R. K. G. J. N. DANZIGER, "Cyber slacking: Workplace Status and Personal Internet Use at Work," Cyber Psychology \& Behavior, vol. 11, no. 3, 2008.

[4] P. Z. M. d. Lara, D. V. Tacoronte and J.-M. T. Ding, "o current anti-cyber loafing disciplinary practices have a replica in research findings? A study of the effects of coercive strategies on workplace Internet misuse," Internet Research, vol. 16, no. 04, pp. 450-467, 2006.

[5] H. Jia, R. Jia and S. Karau, "Cyber loafing and Personality: The Impact of the Big Five Traits and Workplace Situational Factors," Journal of Leadership \& Organizational Studies, vol. 20, no. 3, pp. 358-365, 2013.

[6] A. L. B. a and C. A. Henle, "Correlates of different forms of cyber loafing: The role of norms and external locus of control," Computers in Human Behavior, vol. 24, no. 3, pp. 1067-1084, 2007. 